ORIGINAL ARTICLE / ARTIGO ORIGINAL

\title{
Factors associated with providing social security benefits for traumatic brain injury resulting from occupational accidents
}

\section{Fatores associados à concessão de benefício previdenciário por traumatismo cranioencefálico decorrente de acidente de trabalho}

\author{
Denismar Borges de Miranda', Rita Franco Rego', Denise Nunes Viola', \\ Verônica Maria Cadena Lima', Edriene Barros Teixeira',"I
}

\begin{abstract}
Introduction: The Occupational Accident $(\mathrm{OA})$ is considered to be an important public health problem in Brazil. Traumatic Brain Injury (TBI) is the most common among them. The TBI is associated with high morbidity and mortality rates among workers. Objective: To identify factors associated with providing social security benefits for TBI due to occupational accidents according to the specific type of economic activity in Brazil, in 2009. Methods: This is a cross-sectional study that was conducted with all workers who were part of the General Regime of Social Security (RGPS) of Brazil. Secondary data were obtained from the National Information System Benefit, from the Synchronized National Register of the Ministry of Finance and from the General Register of Employed and Unemployed Persons. Data were analyzed using the multiple logistic regression method. Results: We analyzed 2,006 cases of social security benefits for traumatic brain injury due to Occupational Accident. Factors associated with the concession of the benefit according to the economic activity of the Company of the beneficiary were identified. Associations were found with sex, income and the region of the Company. Conclusion: Factors associated with the concession of social security benefits by TBI resulting from OA differ depending on the type of economic activity in the study. Understanding these factors may contribute to the planning of preventive policies.
\end{abstract}

Keywords: Accidents, occupational. Brain injuries. Craniocerebral trauma. Social Security. Insurance, accident. Occupational health.

'Programa de Pós-graduação em Saúde, Ambiente e Trabalho da Universidade Federal da Bahia - Salvador (BA), Brasil. "Instituto Nacional do Seguro Social - Salvador (BA), Brasil.

Corresponding author: Denismar Borges de Miranda. Rua 18 Norte, lotes 01 e 03, Condomínio Wave, apartamento 1003-B, CEP: 71910-720, Águas Claras, Brasília, DF, Brasil. E-mail: denismarmiranda@hotmail.com

Conflict of interests: nothing to declare - Financial support: none. 
RESUMO: Introdução: O Acidente de Trabalho (AT) é considerado um importante agravo à saúde do trabalhador no Brasil, sendo o Traumatismo Cranioencefálico (TCE) o mais comum dentre eles. O TCE está associado a altas taxas de morbidade e mortalidade entre trabalhadores. Objetivo: Verificar os fatores associados à concessão de benefícios previdenciários por TCE decorrentes de acidente de trabalho de acordo com o ramo de atividade econômica específica, no Brasil, em 2009. Métodos: Trata-se de estudo epidemiológico de corte transversal que foi conduzido com todos os trabalhadores que integram o Regime Geral da Previdência Social (RGPS) do Brasil. Dados secundários foram obtidos do Sistema Único de Informações de Benefícios, do Cadastro Sincronizado Nacional do Ministério da Fazenda e do Cadastro Geral de Empregados e Desempregados e analisados utilizando-se regressão logística múltipla. Resultados: Foram analisados 2.006 casos de benefícios previdenciários por TCE decorrentes de AT no Brasil, e identificaram-se fatores associados à concessão do benefício diferenciados de acordo com a seção da Classificação Nacional de Atividades Econômicas à qual o beneficiário estava vinculado. Foram encontradas associações com o sexo, a renda e a região da empresa. Conclusão: Os fatores associados à concessão de benefícios previdenciários por TCE decorrentes de AT diferem a depender da CNAE em estudo. A compreensão desses fatores poderá contribuir com o planejamento de políticas públicas de caráter preventivo.

Palavras-chave: Acidentes de trabalho. Traumatismos encefálicos. Traumatismos craniocerebrais. Previdência Social. Seguro por acidentes. Saúde do trabalhador.

\section{INTRODUCTION}

The Occupational Accident (OA) is considered to be an important condition to the health of the worker and constitutes an important public health problem. Traumatic brain injury (TBI) related to work is the most common OA, being associated to high morbidity and mortality rates ${ }^{1}$. In Brazil, an increase of more than $30 \%$ has been observed in the cases of TBI caused by OA in the past few years, with 3,242 cases registered in $2005^{2}$ and 4,356 in $2010^{3}$.

Occupational Accident is understood as injuries originated from external causes, as well as traumas and poisonings that happen at work and/or on the commute home-work and viceversa $^{4}$. TBI is considered to be any traumatic aggression that leads to anatomical lesion, such as skull fracture or scalp injury, or even functional meningeal, brain or vessel compromise. TBI can be classified as mild, moderate or severe, according to the score in the Glawgow coma scale 5 .

In Brazil, employees who are hired according to the Consolidation of Labor Laws (CLT) and suffer an OA, therefore becoming unable to work, are entitled to a social security benefit caused by $\mathrm{OA}^{6}$. When this inability overcomes the period of 15 days, employees are advised to request the social security benefit (SSB). The payment of this 
benefit is a responsibility of the National Institute of Social Security (INSS), an autarchy of the Ministry of Social Security (MPS) ${ }^{7}$.

There is no doubt about the economic impact of occupational accidents for the nation. Most especially in countries with advanced technology in the prevention field, the costs of occupational accidents are rarely computed ${ }^{8}$. A Brazilian study that used the registers of conceived social security benefits by OA in 2000 identified a cost estimate of R $\$ 8.5$ million, with approximately half a million missed working days in that year?.

All of the benefited workers submitted to the General Regime of Social Security (RGPS) are connected to companies that are classified according to their field of economic activity (National Classification of Economic Activities (CNAE)). For some authors, the type of CNAE is associated with the risk of suffering an $\mathrm{OA}^{9}$. In 2000, among the CNAEs that generated more $\mathrm{OA}$ are the sections of construction, commerce, transportation, and transformation industries ${ }^{9}$.

Among the factors that contribute with OA, the ones concerning individuals stand out: sex, age, schooling, life conditions, physical and emotional health status, motivation, interest, among others ${ }^{10,11}$, and those related to the working process, such as organization of work and environmental conditions ${ }^{10,12}$.

A previous exploratory study observed the higher incidence of the social security benefit due to TBI resulting from OA in Brazil, in 2009, in the following sections of CNAE: Transport, Storage and Mail (12.98/100,000 contracts a year); Water, Sewage, Activities of Waste Management and Decontamination (12.25/100,000 contracts a year); Construction (8.11/100,000 contracts a year); Public Administration, Defense and Social Security (7.18/100,000 contracts a year); and Commerce, Automobile and Motorcycle Repair $(7.06 / 100,000 \text { contracts a year })^{13}$.

Such results led the authors to propose this study, which aimed at verifying the factors associated to the concession of social security benefits due to TBI caused by AO according to the specific field of economic activity, in Brazil, in 2009.

\section{METHODS}

A cross-sectional epidemiological study was conducted was conducted with all of the employees who received the social security benefit due to TBI caused by OA (typical and on commute) in 2009, codified as B91, who integrate the RGPS in Brazil. Individual contributors and household staff were excluded, since they are not entitled to the accident benefit. It is worth to mention that statutory public employees are not part of the studied population, once they are not included in the RGPS; however, those in different spheres (municipal, state, federal or military) that are hired according to CLT are part of the study population. In 2009, 2,022 accident social security benefits were conceived due to TBI in Brazil. From these benefits, 16 companies appeared as being shut down in CNAE, that is, suspended by the Federal revenue of Brazil ${ }^{13}$. The latter were excluded from the data base for analysis, 
because these 16 registers had missing data, which made it impossible to conduct statistical calculations. Therefore, the total study population consisted of employees who had the benefit due to TBI caused by AO in 2009, accounting for 2,006 individuals.

All of the workers who first entered the system in 2009 (the beginning of the benefit between January $1^{\text {st }} 2009$ and December $31^{\text {st }} 2009$ ) and who presented with the following diagnoses, according to the International Classification of Diseases (ICD), $10^{\text {th }}$ revision (S06 to S06.9), being compatible with TBI. Workers whose benefit was conceived in previous years or whose benefits were reopened in the period of the study were excluded from the study. Data collection was conducted in September 2010.

Data are originated from three secondary sources: the National Information System Benefit (SUIBE), the Synchronized National Register of the Ministry of Finance (MF $)^{14}$ and the General Register of Employed and Unemployed Persons (CAGED), of the Ministry of Work and Employment (MTE) ${ }^{15}$. After obtaining the socioeconomic and social security data related to the benefits conceived due to TBI caused by OA in Brazil, in 2009, which were provided by SUIBE, these data were crossed with the data base of CAGED, considering the National Juridical Person Registration (CNPJ). Therefore, the main CNAE (version 2.0) was obtained, as well as the date of enrollment of the company. These data were grouped in a single data base and processed by the software Statistical Package for the Social Sciences (SPSS), version 15.0 $0^{16}$.

The Cumulative Incidence (CI) coefficient was calculated and given by the following equation: $\mathrm{CI}=(\mathrm{NBP} 2009 / \mathrm{MMA}) \times 100,000$, in which NBP2009 is the number of social security beneficiaries due to TBI caused by OA, in the work place, according to specific CNAE in 2009, and MMA is the annual average of work contracts enrolled to CAGED in the specific CNAE, in the work place, in 2009. The option to calculate the annual monthly mean was chosen to reduce the possibility for the worker (work contract) to be computed more than once, in case this person had been fired and then rehired in the same year. However, it is not possible to detect the mistakes caused by the multiple contracts of a single employee, in case there are any.

The annual CI of benefits due to TBI caused by OA in Brazil, in 2009, was of 6.1 cases per 100,000 work contracts enrolled to CAGED ${ }^{13}$. The five most incident CNAEs were considered individually in this study. They were codified and shaped into: Transport, Storage and Mail (CNAE-H), Water, Sewage and Activities of Waste Management and Decontamination (CNAE-E); Construction (CNAE-F); Public Administration, Defense and Social Security (CNAE-O); and Commerce, Automobile Repair and Motorcycle Repair (CNAE-G). The dependent variable was the social security benefit due to TBI caused by OA for each one of these five CNAE.

The independent variables of the study include factors related to the beneficiary, as well as sociodemographic and social security factors and those related to the company. Sociodemographic factors include: sex (female or male); age of the beneficiary (in full years); wage (benefit wage of the victim, classified in more than four minimum wages (MW), 
more than three and less than or equal to four MW, more than two and less than or equal to three MW, more than one and less than or equal to two MW, and up to one MW); and type of cluster (classification of the characteristic of the city of residency of the victim into countryside or city). The considered minimum wage value in this study was of $\mathrm{R} \$ 465.00$ in 2009. Social security benefits include: time of social security contribution (corresponding to the time of social security contribution until the date the benefit was received - full years); previous social security benefit (corresponding to the existence of a social security benefit prior to 2009, regardless of type, B91 or B31, classified as present or absent); and time for benefit concession (referring to the latency period, in days, between the day when the benefit was requested to social security and the period until its concession, categorized into up to 30 days or more than 30 days). The factors associated with the company are composed of natural region (comprehending the Brazilian geographic region where the company is located, categorized into Southeast, North, Northeast, Center-West or South) and time of company function (representing the period, in full years, since the company was opened until the concession of the benefit).

The descriptive stage consisted of the calculation of means and standard deviations for the continuous independent variables and frequencies for qualitative variables. The Prevalence Ratio (PR) was used as an association measure. Therefore, the next stage consisted of the calculation of crude Prevalence Ratios (cPR) between qualitative independent variables and the dependent variable of the social security benefit due to TBI caused by OA, referring to each of the CNAE, and the calculation of their respective $95 \%$ confidence intervals $(95 \% \mathrm{CI})$.

In order to analyze which independent variables were associated to the social security benefit due to TBI caused by OA in CNAE H, for instance, a multiple logistic regression model was adjusted ${ }^{17}$ with the software $\mathrm{R}$ for Windows. Cases are the situations of social security benefit due to TBI caused by OA in CNAE H, and controls are all of the benefits due to TBI caused by OA for all of the other CNAE. The same analysis was performed in relation to the other four most incident CNAEs. It is worth to mention that the logistic regression analysis uses Odds Ratio (OR) as a measure of effect, and not the PR or Relative Risk (RR), which are natural measures for cross-sectional and longitudinal studies ${ }^{18}$, respectively. Therefore, after the adjustment of the logistical model, the adjusted prevalence ratio (aPR) was estimated based on model coefficients, and the $95 \%$ CI was calculated by means of the delta method ${ }^{19}$.

For each of the CNAE, a logistic regression model was adjusted with all of the independent variables, and based on the backward selection method, a final model was obtained and assessed according to the likelihood ratio test and the Wald statistic test, considering a $5 \%$ significance level.

In this study, the choice was to adjust the model to the continuous variables (age of the beneficiary, time of social security contribution and time of company functioning), since the transformation of these variables into categories would lead to loss of 
information. Therefore, the aPR and its $95 \% \mathrm{CI}$ were calculated only in relation to categorical variables, considering the possible effect of any continuous variable that had remained in the final model.

Based on the final logistic regression model, the probability of the beneficiary of TBI caused by AO belonging to the group of interest (CNAE) was also calculated, given the presence of independent variables ${ }^{17}$.

Since these are administrative data, and because the identities of the workers and companies are not present in the data bases, the protocol was not submitted to the Research Ethics Committee. However, this study respects the ethical principles of Resolution n. 196/96 and began after the signature of the institutional informed consent form and authorization to use the data base from SUIBE, by the board of INSS.

\section{RESULTS}

The mean age of beneficiaries of TBI caused by OA in Brazil, in 2009, in the five most incident sections of CNAE, ranged from 32.7 years old, with standard deviation (SD) of 11.5 years for CNAE-G, and from 38.9 years old ( $\mathrm{SD}=14.6$ years) for CNAE-E. The mean time of social security contribution, it ranged from 7.1 years (SD $=6.9$ years) in CNAE-F to 11.4 years $(\mathrm{SD}=8.9$ years $)$ in CNAE-E.

The average, in years, of company functioning that employed the beneficiaries of TBI caused by AO in Brazil, in 2009, ranged from 11.3 years (SD = 99.9 years) in section CNAE-G to 28.9 years ( $\mathrm{SD}=14.2$ years), in section CNAE-O.

Table 1 presents the annual CI of social security beneficiaries of TBI caused by OA in Brazil, in 2009. The highest CI of the beneficiary of TBI caused by OA was in the Transport, Storage and Mail section, with 12.98/100,000 contracts a year. The other CNAE with higher incidences were: Water, Sewage, Activities of Waste Management and Decontamination; Construction; Public Administration, Defense and Social Security; and Commerce; Automobile and Motorcycle Repair, respectively. The sections of CNAE with incidences lower than $6.1 / 100,000$ contracts a year were grouped in the "others" category.

In Tables 2 and 3, according to the crude PR and 95\%CI, the factors associated with social security benefits of TBI caused by OA in 2009, in Brazil, for CNAE H were: being male, earning from two to three MW and earning less than one MW; for CNAE-E, type of interior cluster; for CNAE-F, being male; for CNAE-O, earning less than three MW; for section CNAE-G, earning less than two MW, having received a previous social security benefit and the company being from the South region.

As demonstrated in Table 4, factors associated with the concession of social security benefits of TBI caused by OA in the section of Transport, Storage and Mail from CNAE (CNAE-H) were: male $(\mathrm{aPR}=2.93 ; 95 \% \mathrm{CI} 1.61-5.31)$, wage range higher than two or equal to three $\mathrm{MW}(\mathrm{aPR}=2.00 ; 95 \% \mathrm{CI} 1.07-3.72)$ and wage range lower than one $\mathrm{MW}$ $(\mathrm{aPR}=0.40 ; 95 \% \mathrm{CI} 0.19-0.86)$. There were no confusion factors between variables. 
The possibility of receiving accident social security benefits of TBI working in companies classified in the field of Transport, Storage and Mail, being male and earning more than two or less than or three minimum wages is of $27.13 \%$.

For the section of Water, Sewage, Activities of Waste Management and Decontamination (CNAE-E), the beneficiary living in the capital is more exposed to the concession of the social security benefit of TBI caused by OA, when compared to the beneficiary living in the countryside $(\mathrm{aPR}=0.45 ; 95 \% \mathrm{CI} 0.22-0.91$ ) (Table 4$)$. The probability of receiving social security benefit of TBI in Brazil and working in a company in the field of Water, Sewage, Activity of Waste Management and Decontamination is of 1.31 and $2.91 \%$, considering the person who lives in the countryside and in the capital, respectively.

The CNAE-F section represents the Construction field. There were no confusion factors between variables. For this model, the factor associated with the concession of social security of TBI caused by OA was being male, with prevalence ratio of 6.67 (95\%CI $2.76-16.12$ ), age and time of contribution (Table 4). The probability of receiving the social security

Table 1. Incidence of social security benefit by traumatic brain injury resulting from occupational accidents by annual average of labor contracts according to the section of the National Classification of Economic Activities in Brazil, 2009.

\begin{tabular}{|c|c|c|c|c|c|}
\hline \multirow[t]{2}{*}{ CNAE section } & \multicolumn{2}{|c|}{$\begin{array}{l}\text { Frequency of } \\
\text { the benefit }\end{array}$} & \multicolumn{2}{|c|}{$\begin{array}{l}\text { Annual mean } \\
\text { of work contracts }\end{array}$} & \multirow{2}{*}{ 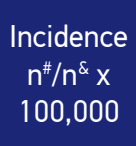 } \\
\hline & $\mathrm{n}^{\#}$ & $\%$ & $n^{\S}$ & $\%$ & \\
\hline Transport, Storage and Mail $(\mathrm{H})$ & 248 & 12.27 & 1.911 .100 & 5.80 & 12.98 \\
\hline $\begin{array}{l}\text { Water, Sewage and Activities } \\
\text { of Waste Management and } \\
\text { Decontamination (E) }\end{array}$ & 33 & 1.63 & 269.423 & 0.82 & 12.25 \\
\hline Construction (F) & 202 & 9.99 & 2.490 .089 & 7.56 & 8.11 \\
\hline $\begin{array}{l}\text { Public Administration, } \\
\text { Defense and Social Security (0) }\end{array}$ & 53 & 2.62 & 738.007 & 2.24 & 7.18 \\
\hline $\begin{array}{l}\text { Commerce, Automobile and } \\
\text { Motorcycle Repair (G) }\end{array}$ & 528 & 26.11 & 7.480 .532 & 22.71 & 7.06 \\
\hline Others & 942 & 46.59 & 20.045 .655 & 60.87 & 4.70 \\
\hline $\mathrm{NL}^{\S}$ & 16 & 0.79 & - & - & - \\
\hline Total & 2.022 & 100.00 & 32.934 .806 & 100.00 & 6.14 \\
\hline
\end{tabular}

"Absolute frequency of social security benefits granted by traumatic brain injury resulting from occupational accidents in Brazil according to the National Classification of Economic Activities specifically in 2009. ¿Annual average of work contracts in Brazil according to the specific National Classification of Economic Activities in 2009. ${ }^{5}$ Not located (downsized, closed and/or suspended company).

Source: Table, modified partially, from the article - Miranda DB, Viola DN, Lima VMC, Rêgo MAV, Teixeira EB, Rêgo RF. Security benefits of traumatic brain injury due to occupational accidents. Rev Enferm UFPE OnLine 2012; 6(6): 1311-20 
Table 2. Frequency and crude prevalence ratio for benefit for traumatic brain injury resulting from accident at work for each section National Classification of Economic Activities in Brazil, 2009 in relation to sociodemographic variables $(n=2,006)$.

\begin{tabular}{|c|c|c|c|c|c|c|c|c|c|c|c|c|c|c|c|}
\hline \multicolumn{16}{|c|}{ CNAE Section } \\
\hline \multirow{2}{*}{ Variables } & \multicolumn{3}{|c|}{$\begin{array}{l}\text { Transport, Storage } \\
\text { and Mail }(\mathrm{H})\end{array}$} & \multicolumn{3}{|c|}{$\begin{array}{c}\text { Water, Sewage and Activities } \\
\text { of Waste Management } \\
\text { and Decontamination (E) }\end{array}$} & \multicolumn{3}{|c|}{ Construction (F) } & \multicolumn{3}{|c|}{$\begin{array}{l}\text { Public Administration, } \\
\text { Defense and Social } \\
\text { Security }(0)\end{array}$} & \multicolumn{3}{|c|}{$\begin{array}{l}\text { Commerce, Automobile } \\
\text { and Motorcycle Repair (G) }\end{array}$} \\
\hline & $\begin{array}{l}n= \\
248\end{array}$ & $\%$ & $\begin{array}{c}\mathrm{RP} \\
95 \% \mathrm{Cl}\end{array}$ & $\begin{array}{l}n= \\
33\end{array}$ & $\%$ & $\begin{array}{c}\mathrm{RP} \\
95 \% \mathrm{Cl}\end{array}$ & $\begin{array}{l}n= \\
202\end{array}$ & $\%$ & $\begin{array}{c}\mathrm{RP} \\
95 \% \mathrm{Cl}\end{array}$ & $\begin{array}{l}n= \\
53\end{array}$ & $\%$ & $\begin{array}{c}\mathrm{RP} \\
95 \% \mathrm{Cl}\end{array}$ & $\begin{array}{l}n= \\
538\end{array}$ & $\%$ & $\begin{array}{c}\mathrm{RP} \\
95 \% \mathrm{Cl}\end{array}$ \\
\hline \multicolumn{16}{|l|}{ Sex } \\
\hline Female & 11 & 4.02 & 1.00 & 5 & 1.83 & 1.00 & 5 & 1.83 & 1.00 & 20 & 7.32 & 1.00 & 74 & 27.10 & 1.00 \\
\hline \multirow[t]{2}{*}{ Male } & 237 & 13.67 & 3.39 & 28 & 1.61 & 0.88 & 197 & 11.36 & 6.21 & 33 & 1.90 & 0.26 & 454 & 26.19 & 0.97 \\
\hline & & & $1.88-6.13$ & & & $0.34-2.27$ & & & $2.58-14.94$ & & & $0.15-0.45$ & & & $0.78-1.19$ \\
\hline \multicolumn{16}{|l|}{ Wage range } \\
\hline$>4$ & 9 & 12.85 & 1.00 & 2 & 2.85 & 1.00 & 3 & 4.28 & 1.00 & 6 & 8.57 & 1 & 11 & 15.71 & 1.00 \\
\hline \multirow[t]{2}{*}{$3-4$} & 25 & 25.25 & 1.96 & 3 & 3.03 & 1.06 & 6 & 6.06 & 1.41 & 4 & 4.04 & 0.47 & 11 & 11.11 & 0.71 \\
\hline & & & $0.98-3.95$ & & & $0.18-6.18$ & & & $0.37-5.46$ & & & $0.14-1.61$ & & & $0.32-1.54$ \\
\hline \multirow[t]{2}{*}{$2-3$} & 74 & 25.96 & 2.02 & 6 & 2.10 & 0.74 & 32 & 11.22 & 2.62 & 8 & 2.80 & 0.33 & 46 & 16.14 & 1.03 \\
\hline & & & $1.06-3.83$ & & & $0.15-3.57$ & & & $0.83-8.31$ & & & $0.12-0.91$ & & & $0.56-1.88$ \\
\hline \multirow[t]{2}{*}{$1-2$} & 117 & 10.64 & 0.83 & 19 & 1.72 & 0.61 & 117 & 10.64 & 2.48 & 27 & 2.45 & 0.29 & 305 & 27.75 & 1.77 \\
\hline & & & $0.44-1.56$ & & & $0.14-2.55$ & & & $0.81-7.62$ & & & $0.12-0.67$ & & & $1.02-3.06$ \\
\hline \multirow[t]{2}{*}{$<1$} & 23 & 5.07 & 0.39 & 3 & 0.66 & 0.23 & 44 & 9.71 & 2.27 & 8 & 1.76 & 0.21 & 155 & 34.21 & 2.18 \\
\hline & & & $0.19-0.82$ & & & $0.04-1.36$ & & & $0.72-7.10$ & & & $0.07-0.58$ & & & $1.25-3.08$ \\
\hline \multicolumn{16}{|l|}{ Type of cluster } \\
\hline Capital & 54 & 13.13 & 1.00 & 12 & 2.91 & 1.00 & 49 & 11.92 & 1.00 & 8 & 1.94 & 1.00 & 93 & 22.62 & 1.00 \\
\hline \multirow[t]{2}{*}{ Countryside } & 194 & 12.16 & 0.93 & 21 & 1.31 & 0.45 & 153 & 9.59 & 0.80 & 45 & 2.82 & 1.45 & 435 & 27.27 & 1.21 \\
\hline & & & $0.70-1.23$ & & & $0.22-0.91$ & & & $0.59-1.09$ & & & $0.69-3.05$ & & & $0.99-1.47$ \\
\hline
\end{tabular}

Source: SUIBE/PS and CAGED/MTE - 2009. 
Table 3. Frequency and crude prevalence ratio for benefit for traumatic brain injury resulting from accident at work for each section National Classification of Economic Activities in Brazil, 2009 in relation to social security and company variables $(n=2,006)$.

\begin{tabular}{|c|c|c|c|c|c|c|c|c|c|c|c|c|c|c|c|}
\hline \multicolumn{16}{|c|}{ CNAE Section } \\
\hline \multirow{2}{*}{ Variables } & \multicolumn{3}{|c|}{$\begin{array}{l}\text { Transport, Storage } \\
\text { and Mail }(\mathrm{H})\end{array}$} & \multicolumn{3}{|c|}{$\begin{array}{c}\text { Water, Sewage and Activities } \\
\text { of Waste Management } \\
\text { and Decontamination (E) }\end{array}$} & \multicolumn{3}{|c|}{ Construction (F) } & \multicolumn{3}{|c|}{$\begin{array}{l}\text { Public Administration, } \\
\text { Defense and Social } \\
\text { Security (0) }\end{array}$} & \multicolumn{3}{|c|}{$\begin{array}{l}\text { Commerce, Automobile } \\
\text { and Motorcycle Repair (G) }\end{array}$} \\
\hline & $\begin{array}{l}n= \\
248\end{array}$ & $\%$ & $\begin{array}{c}\mathrm{RP} \\
95 \% \mathrm{Cl}\end{array}$ & $\begin{array}{l}\mathrm{n}= \\
33\end{array}$ & $\%$ & $\begin{array}{c}\mathrm{RP} \\
95 \% \mathrm{Cl}\end{array}$ & $\begin{array}{l}\mathrm{n}= \\
202\end{array}$ & $\%$ & $\begin{array}{c}\mathrm{RP} \\
95 \% \mathrm{Cl}\end{array}$ & $\begin{array}{c}n= \\
53\end{array}$ & $\%$ & $\begin{array}{c}\mathrm{RP} \\
95 \% \mathrm{Cl}\end{array}$ & $\begin{array}{l}n= \\
538\end{array}$ & $\%$ & $\begin{array}{c}\mathrm{RP} \\
95 \% \mathrm{Cl}\end{array}$ \\
\hline \multicolumn{16}{|c|}{ Previous social security benefit } \\
\hline Present & 0 & 0.00 & 1.00 & 0 & 0.00 & 1.00 & 4 & 14.28 & 1.00 & 0 & 0.00 & 1.00 & 14 & 50.00 & 1.00 \\
\hline \multirow[t]{2}{*}{ Absent } & 248 & 12.53 & 0 & 33 & 1.66 & 0 & 198 & 10.01 & 0.70 & 53 & 2.67 & 0 & 514 & 25.98 & 0.52 \\
\hline & & & & & & & & & $0.28-1.75$ & & & & & & $0.36-0.76$ \\
\hline \multicolumn{16}{|l|}{ Natural region } \\
\hline Southeast & 130 & 13.85 & 1.00 & 16 & 1.70 & 1.00 & 98 & 10.44 & 1.00 & 25 & 2.66 & 1.00 & 263 & 28.03 & 1.00 \\
\hline \multirow[t]{2}{*}{ North } & 4 & 4.59 & 0.33 & 1 & 1.14 & 0.67 & 11 & 12.64 & 1.21 & 4 & 4.59 & 1.73 & 31 & 35.63 & 1.27 \\
\hline & & & $0.13-0.88$ & & & $0.09-5.02$ & & & $0.68-2.17$ & & & $0.61-4.84$ & & & $0.94-1.72$ \\
\hline \multirow[t]{2}{*}{ Northeast } & 30 & 10.03 & 0.72 & 3 & 1.00 & 0.59 & 40 & 13.37 & 1.28 & 11 & 3.67 & 1.38 & 74 & 24.74 & 0.88 \\
\hline & & & $0.50-1.05$ & & & $0.17-2.00$ & & & $0.91-1.81$ & & & $0.69-2.77$ & & & $0.71-1.10$ \\
\hline \multirow[t]{2}{*}{ Center-West } & 25 & 12.50 & 0.90 & 7 & 3.50 & 2.05 & 15 & 7.50 & 0.72 & 3 & 1.50 & 0.56 & 50 & 25.00 & 0.89 \\
\hline & & & $0.60-1.35$ & & & $0.86-4.92$ & & & $0.43-1.21$ & & & $0.17-1.85$ & & & $0.69-1.16$ \\
\hline \multirow[t]{2}{*}{ South } & 59 & 12.24 & 0.88 & 6 & 1.24 & 0.73 & 38 & 7.88 & 0.75 & 10 & 2.07 & 0.78 & 110 & 22.82 & 0.81 \\
\hline & & & $0.62-1.18$ & & & $0.29-1.85$ & & & $0.53-1.08$ & & & $0.38-1.61$ & & & $0.67-0.99$ \\
\hline \multicolumn{16}{|c|}{ Time for benefit concession } \\
\hline Up to 30 days & 206 & 12.12 & 1.00 & 29 & 1.70 & 1.00 & 165 & 9.71 & 1.00 & 48 & 2.82 & 1.00 & 445 & 26.19 & 1.00 \\
\hline \multirow[t]{2}{*}{$>30$ days } & 42 & 13.68 & 1.13 & 4 & 1.30 & 0.76 & 37 & 9.32 & 0.96 & 5 & 1.62 & 0.58 & 83 & 27.03 & 1.03 \\
\hline & & & $0.83-1.54$ & & & $0.27-2.16$ & & & $0.68-1.35$ & & & $0.23-1.44$ & & & $0.84-1.26$ \\
\hline
\end{tabular}

Source: SUIBE/PS and CAGED/MTE - 2009. 
Table 4. Associated factors with the grant of social security benefits for traumatic brain injury resulting from occupational accidents in the section of the National Classification of Economic Activities specific in Brazil, 2009.

\begin{tabular}{|c|c|c|c|c|}
\hline CNAE & \multicolumn{2}{|c|}{ Variables } & Adjusted PR & $95 \% \mathrm{Cl}$ \\
\hline \multirow{7}{*}{$\mathrm{H}$} & \multirow{2}{*}{ Sex } & Female & 1.00 & \\
\hline & & Male & 2.93 & $1.61-5.31$ \\
\hline & \multirow{5}{*}{ Wage Range (MW) } & $>4$ & 1.00 & \\
\hline & & $3-4$ & 1.94 & $0.98-3.82$ \\
\hline & & $2-3$ & 2.00 & $1.07-3.72$ \\
\hline & & $1-2$ & 0.81 & $0.42-1.56$ \\
\hline & & $<1$ & 0.40 & $0.19-0.86$ \\
\hline \multirow{2}{*}{$E$} & \multirow{2}{*}{ Type of cluster } & Capital & 1.00 & \\
\hline & & Countryside & 0.45 & $0.22-0.91$ \\
\hline \multirow{2}{*}{$\mathrm{F}$} & \multirow{2}{*}{ Sex } & Female & 1.00 & \\
\hline & & Male & 6.67 & $2.76-16.12$ \\
\hline \multirow{9}{*}{0} & \multirow{2}{*}{$\operatorname{Sex}^{£}$} & Female & 1.00 & \\
\hline & & Male & 0.24 & $0.13-0.44$ \\
\hline & \multirow{5}{*}{ Wage range ${ }^{\delta}$} & $>4$ & 1.00 & \\
\hline & & $3-4$ & 0.37 & $0.09-1.47$ \\
\hline & & $2-3$ & 0.31 & $0.09-0.99$ \\
\hline & & $1-2$ & 0.36 & $0.13-0.96$ \\
\hline & & $<1$ & 0.28 & $0.08-0.91$ \\
\hline & \multirow{2}{*}{ Type of cluster ${ }^{\S}$} & Capital & 1.00 & \\
\hline & & Countryside & 2.38 & $1.06-5.31$ \\
\hline \multirow{12}{*}{ G } & \multirow{5}{*}{ Wage range ${ }^{\S}$} & $>4$ & 1.00 & \\
\hline & & $3-4$ & 0.76 & $0.37-1.59$ \\
\hline & & $2-3$ & 1.00 & $0.58-1.73$ \\
\hline & & $1-2$ & 1.67 & $1.00-2.78$ \\
\hline & & $<1$ & 1.93 & $1.24-3.00$ \\
\hline & \multirow{2}{*}{$\begin{array}{l}\text { Previous social } \\
\text { security benefit }{ }^{\S}\end{array}$} & Present & 1.00 & \\
\hline & & Absent & 0.51 & $0.34-0.76$ \\
\hline & \multirow{5}{*}{ Natural region ${ }^{\S}$} & Southeast & 1.00 & \\
\hline & & North & 1.15 & $0.81-1.62$ \\
\hline & & Northeast & 0.76 & $0.59-0.98$ \\
\hline & & Center-West & 0.80 & $0.60-1.06$ \\
\hline & & South & 0.77 & $0.63-0.95$ \\
\hline
\end{tabular}

\#Adjusted by age and time of social security contributions. ${ }^{\circledR}$ Adjusted by age and time of operation of businesses. ${ }^{\S}$ Adjusted by time of operation of businesses.

Source: SUIBE/PS and CAGED/MTE - 2009. 
benefit of TBI caused by OA in the Construction sector being a 20 year-old male with time of contribution of three years is of $8.27 \%$. The increased probability is observed with age, that is, by considering the variables described in the first case, for a 40 year-old men, the probability goes up to $16.34 \%$. The opposite occurs when the time of contribution increases, for instance, after 20 years of contribution, and by keeping the other variables stable in the first case, the probability is of $3.39 \%$.

The factors associated with the concession of social security benefit of TBI caused by $\mathrm{OA}$ in the sector of Public Administration, Defense and Security (CNAE-O) were: being male; wage range; type of cluster; age of the beneficiary; and time of company functioning. There were no confusion variables in the model. The probability of receiving the social security benefit of TBI caused by OA in a company of the Administration, Defense and Security Sector, by working in a company that has been functioning for five years, being 30 years old, being male, with more than four minim wages and living in the countryside is of $1.29 \%$; living in the capital, of $0.54 \%$. When compared to females, by maintaining the same conditions, the probability goes up to 5.36 and 2.30, living in the countryside and in the capital, respectively.

The factors associated with the concession of the accident benefit of TBI caused by $\mathrm{OA}$ in the section of Commerce, Automobile and Motorcycle Repair (CNAE-G) were: wage range; previous social security benefit; natural region; and time companies operate. The probability of the victim of TBI working in the CNAE-G, considering the fact of not having received previous social security support, working in a company that has been working for five years, receiving up to two minimum wages and living in the Southeast region is of $60.32 \%$; the probability decreases when the wage increases (more than two minimum wages) - and by keeping the same variables of the first case, the probability is of $17.72 \%$. There were no confusion variables.

\section{DISCUSSION}

The factors associated to the concession of the social security benefit of TBI caused by $\mathrm{OA}$ in Brazil are different depending on the field of economic activity in which the worker is inserted. It was observed that the CNAE sections of Transport, Storage and Mail; Water, Sewage, and Activities of Waste Management and Decontamination; Construction; Public Administration, Defense and Social Security; and Commerce, Automobile and Motorcycle Repair form the group of analysis in this study and represent the five highest incidences of social security concession of TBI caused by OA in Brazil, in 2009. This group of CNAE sessions is also nationally known for presenting higher social security costs and missed work days $^{9}$, as well as for composing the mortality ranking of TBI caused by OA in Canada ${ }^{1}$.

For the activity of Transport, Storage and Mail, a higher prevalence ratio was observed among men, besides the fact of earning more than two, three or less MW. The possible justifications of the association between the male gender and the higher occurrence of 
conceiving social security benefit of TBI caused by OA in this CNAE can be understood as a product of the male behavior to the social environment ${ }^{21}$. Some authors emphasize factors that can possibly be related to this behavior, which is more vulnerable to OA affecting workers in the load transport field in general. Among these factors is the effect of positive pressure for productivity ${ }^{22}$, in which exhausting work, usually performed under the effect of psychoactive stimulators, predisposes to risk conditions for OA. The same association was found for males in a study conducted with workers who perform general transport and transport of hazardous substances in the state of São Paulo ${ }^{23}$. The same explanatory argument can be used to justify the male gender as being a risk factor found in the CNAE sections of Construction and Public Administration, Defense and Security.

The results found with regard to the economic activity Water, Sewage, and Activities of Waste Management and Decontamination indicated that living in the capital was considered to be the only factor associated with the concession of the social security benefit of TBI caused by OA. Such evidence can be related to the amplification of work addressed to the structure of water and sewage networks in major urban centers. There are data in national literature indicating that the larger the size of the city, the larger the constructions and structures of water and sewage connections ${ }^{24}$.

Living in the countryside is associated with the concession of social security benefit of TBI caused by OA in the CNAE section of Public Administration, Defense and Security in Brazil, in 2009. This group is composed of companies in the municipal, state, federal or military spheres, and employees are hired by CLT. The little control of Regional Work Stations in country cities ${ }^{25}$, as well as the lack of public policies to prevent the occurrence of accidents inside the states ${ }^{26}$ and the precariousness in the adoption of methods that minimize the risk for $\mathrm{OA}$ in older companies ${ }^{27}$ can be some of the justifications for these results.

For the CNAE section of commerce, Automobile and Motorcycle Repair, the factors considered to have more exposure for the concession of the social security benefit of TBI caused by OA were presenting low income, especially the wage range of up to one MW. The probability of receiving social security income of TBI caused by OA was of $60.32 \%$ for workers who earned up to two MW, controlled by the other variables that compose the final model (not having received social security benefits before and working in a company that has been working for five years). A study developed in Portugal points out that the industries in the Commerce field are more prone to paying low salaries, which confirms the profile of workers in this sector ${ }^{28}$. It is worth to emphasize that this group of economic activity comprehends a large number of companies with different profiles, and any interpretation of risk factors associated with the concession of the social security benefit of TBI caused by $\mathrm{OA}$ in this CNAE should be made carefully.

It is important to emphasize that the results in this study should be analyzed carefully due to the limitations found in the data base, as described in other studies that used similar methods ${ }^{29}$. Data bases are valuable sources to analyze health issues, however, the difficulties to operate these data should be acknowledged, for instance, limitations in the quality of the collected data and the non-existence of other variables of interest for this type of study. 
It is worth to mention that the option of only using the social security benefit (B91) as a consequence of accidents as an outcome for this study may also be understood as a limitation, since underestimates the total social security expenses resulting from TBI caused by OA by not incorporating the accidental disability retirements (E91) and cases of death benefits by AT (E25). Another limitation is related to the profile of the victim who is entitled to receive the social security benefit, when the person is dismissed from work for more than 15 days, which characterizes more severe traumas.

Despite the limitations of national data bases, the authors wish to indicate the importance of using data bases as instruments to elaborate policies for the prevention of occupational accidents according to the field of economic activity.

\section{CONCLUSION}

This study has shown which were the factors associated to the concession of social security benefit of TBI caused by OA in specific CNAE sections in Brazil, in 2009, and that these factors are different depending on the analyzed CNAE section.

Therefore, it was observed that being a man who earns more than two, three or less MW are factors associated with the concession of the social security benefit of TBI caused by OA in the sector of Transport, Storage and Mail; the men are more exposed in the Construction section; companies in the countryside of the state are more exposed in the Public Administration, Defense and Social Security section; and low wage (up to two MW) in the CNAE section of Commerce, Automobile and Motorcycle Repair. For the CNAE section of Water, Sewage, and Activities of Waste Management and decontamination, the only associated factor was the type of cluster.

Understanding the factors associated with the concession of social security benefits of TBI caused by OA in each CNAE section can contribute with the planning of specific preventive public policies for each field of economic activity.

\section{REFERENCES}

1. Tricco A, Colantonio A, Chipman M, Liss G, Mclellan B. Work-related deaths and traumatic brain injury. Brain Injury 2006; 20: 719-24.

2. Ministério da Previdência Social. Instituto Nacional do Seguro Social. Empresa de Tecnologia e Informações da Previdência Social. Anuário Estatístico da Previdência Social. Brasília: MPS / DATAPREV; 2005. 834 p.

3. Ministério da Previdência Social. Instituto Nacional do Seguro Social. Empresa de Tecnologia e Informações da Previdência Social. Anuário Estatístico da Previdência Social. Brasília: MPS/DATAPREV; 2010. 868 p.
4. Brasil. Presidência da República. Decreto n o 611, de 21 de julho de 1992, dá nova redação ao Regulamento dos Benefícios da Previdência Social. Disponível em: http: / / www.010.dataprev.gov.br/sislex/paginas/23/1992/611. htm. (Acessado em 30 de outubro de 2010).

5. Teasdale G, Jennett B. Assessmento f coma and impaired consciousness: a practical scale. Lancet 1974; 2: 81-4.

6. Brasil. Presidência da República. Lei $n^{\circ} 8.212$, de 24 de julho de 1991. Dispõe sobre a organização da Seguridade Social, institui Plano de Custeio, e dá outras providências. Disponível emhttp:/ / www.planalto.gov.br/ccivil_03/Leis/ L8212cons.htm. (Acessado em 25 de novembro de 2010). 
7. Brasil. Senado Federal. Constituição da República Federativa do Brasil de 1988. Disponível em http:/ / www.planalto. gov.br/ccivil_03/constituicao/constitui\%C3\%A7ao.htm. (Acessado em 3 de janeiro de 2011).

8. Dorman P. The economics of safety, health, and wellbeing at work: an overview. Geneva: ILO; 2000.

9. Santana VS, Araújo-Filho JB, Albuquerque-Oliveira PR, Barbosa-Branco A. Acidente de trabalho: custos previdenciários e dias de trabalho perdido. Rev Saude Publica 2006; 40: 1004-12.

10. Mattos UAO. Introdução ao Estudo da Questão Saúde e Trabalho. Rio de Janeiro: Fundação Oswaldo Cruz; 2001.

11. Léplat JXC. Introdução à psicologia do trabalho. Rio de Janeiro: Fundação Calouste Gulbenkian; 2000.

12. Almeida IM. Construindo a culpa e evitando a prevenção: caminhos da investigação de acidentes do trabalho em empresas de município de porte médio [tese de doutorado]. São Paulo: Faculdade de Saúde Pública da USP; 2001. 222 p.

13. Miranda DB, Viola DN, Lima VMC, Rêgo MAV, Teixeira EB, Rêgo RF. Security benefits of traumatic brain injury due to occupational accidents. Rev Enferm UFPE online 2012; 6: 1311-20.

14. Brasil. Receita Federal. Cadastro Sincronizado Nacional. Emissão de Comprovante de Inscrição e de Situação Cadastral. Disponível em: http: / / www.receita.fazenda. gov.br/pessoajuridica/cnpj/cnpjreva/cnpjreva_ solicitacao.asp. (Acessado em 10 de fevereiro de 2010).

15. Brasil. Ministério do Trabalho e Emprego. Cadastro Geral de Empregados e Desempregados. Disponível em: http:/ / cagedestabelecimento.caged.gov.br/tela3 . asp. (Acessado em 22 de setembro de 2010).

16. SPSS Incorporation, 2006. Statistical Package for the Social Sciences - SPSS, Version 15.0. Chicago: SPSS Incorporation; 2006.

17. Hosmer Junior DW, Lemeshow S. Applied logistic regression. New York: John Willey \& Sons; 2000.

18. Hirakata VN. Estudos transversais e longitudinais com desfechos binários: qual a melhor medida de efeito a ser utilizada? Rev HCPA \&Fac Med Univ Fed Rio Gd do Sul 2009; 29: 174-6.
19. Oliveira NF, Santana VS, Lopes AA. Razões de proporções e uso do método delta para intervalos de confiança em regressão logística. Rev Saude Publica 1997; 31: 90-9.

20. Brasil. Ministério da Saúde. Conselho Nacional de Saúde, Comissão Nacional de Ética e Pesquisa. Manual Operacional para Comitês de Ética em Pesquisa. Cadernos Técnicos, n. 133. Brasília: Ministério da Saúde; 2002. p. 83-91.

21. Schraiber LB, Gomes R, Couto MT. Homens e saúde na pauta da saúde coletiva. Cienc Saude Coletiva 2005; 10: 7-17.

22. Moysés SJ. Determinação sociocultural dos acidentes de transporte Terreste (ATT). Cienc Saude Coletiva 2012; 17: 2237-45.

23. Ferreira CEC. Acidentes com motoristas no transporte rodoviário de produtos perigosos. São Paulo Perspect 2001; 17: 68-80.

24. Saiani CCS. Restrições à expansão dos investimentos em saneamento básico no Brasil: déficit de acesso e desempenho dos prestadores [dissertação de mestrado]. Ribeirão Preto: Faculdade de Economia, Administração e Contabilidade da USP; 2006. 315 p.

25. Oliveira MHB, Oliveira LSB, Ribeiro FSN, Vasconcellos LCF. Análise comparativa dos dispositivos de saúde do trabalhador nas constituições estaduais brasileiras. Cad Saude Publica 1997; 13: 425-33.

26. Cordeiro R, Sakate M, Clemente APG, Diniz CS, Donalisio MR. Subnotificação de acidentes do trabalho não fatais em Botucatu, SP, 2002. Rev Saude Publica 2005; 39: 254-60.

27. Oliveira JC. Segurança e saúde no trabalho uma questão mal compreendida. São Paulo. Perspect 2003; 17: 3-12.

28. Cardoso A, Sousa R, Castro V, Ferreira P. O perfil do trabalhador e da empresa de baixos salários em Portugal. Economia 2000;24: 53-66.

29. Souza NSS, Santana VS, Albuquerque-Oliveira PR, Barbosa-Branco A. Work-related diseases and healthrelated compensation claims, Northeastern Brazil, 2000. Rev Saude Publica 2008; 42: 630-8.

Received on: 03/06/2012

Final version presented on: 06/09/2013

Accepted on: 06/14/2013 